\title{
Kemampuan Berpikir Kreatif Matematis dan Resiliensi Matematis
}

\author{
Rizki Agustina Sari ${ }^{1}$, Reni Untarti ${ }^{*}$ \\ 1,2 Pendidikan Matematika, FKIP, Universitas Muhammadiyah Purwokerto, Purwokerto \\ *email: reniuntarti@ump.ac.id
}

\begin{abstract}
Mathematical creative thinking ability is a critical ability in learning mathematics, especially in solving mathematical problems. This research is a qualitative descriptive study that aims to describe the mathematical creative thinking skills based on the mathematical resilience of grade VII F students of SMP Negeri 1 Banyumas. The research subjects were grouped into 3 categories, namely high, medium, and low mathematical resilience categories. The sampling technique used purposive sampling by taking 3 people each in each category to become respondents. Data collection was done by giving questionnaires, written tests, interviews, and documentation which were carried out online. The data analysis technique was done by reducing the data, presenting the data, and drawing conclusions. The results showed: (1) students in the high mathematical resilience category were able to provide a variety of different solutions, as well as come up with new ideas with systematic and detailed answers, (2) students in the moderate mathematical resilience category were able to provide more than one different solution with systematic answers but not detailed, and (3) students in the low mathematical resilience category can solve mathematical problems with systematic.
\end{abstract}

Keywords: Mathematical Creative Thinking Skills; Mathematical Resilience

\begin{abstract}
Abstrak
Kemampuan berpikir kreatif matematis adalah kemampuan yang penting dalam pembelajaran matematika, terlebih dalam penyelesaian permasalahan matematika. Penelitian ini merupakan penelitian deskriptif kualitatif yang bertujuan untuk mendeskripsikan kemampuan berpikir kreatif matematis berdasarkan pada resiliensi matematis siswa kelas VII F SMP Negeri 1 Banyumas. Subyek penelitian dikelompokkan menjadi 3 kategori, yaitu kategori resiliensi matematis tinggi, sedang, dan rendah. Teknik pengambilan sampel menggunakan purposive sampling dengan mengambil masing -masing 3 orang pada setiap kategori untuk dijadikan responden. Pengumpulan data dilakukan dengan pemberian angket, tes tertulis, wawancara, dan dokumentasi yang dilakukan secara online. Teknik analisis data dilakukan dengan reduksi data, penyajian data, dan penarikan kesimpulan. Hasil penelitian menunjukkan: (1) siswa kategori resiliensi matematis tinggi mampu memberikan berbagai penyelesaian berbeda, serta memunculkan ide baru dengan jawaban yang sistematis dan terperinci, (2) siswa kategori resiliensi matematis sedang mampu memberikan lebih dari satu penyelesaian yang berbeda dengan jawaban yang sistematis namun tidak rinci, dan (3) siswa kategori resiliensi matematis rendah mampu menyelesaikan permasalahan matematika dengan jawaban yang sistematis.
\end{abstract}

Kata Kunci: Kemampuan Berpikir Kreatif Matematis; Resiliensi Matematis

\section{PENDAHULUAN}

Pendidikan melalu proses pembelajaran memiliki peranan penting dalam menentukan jati diri individu, membantu membentuk watak seseorang dan mengembangkan kemampuan serta potensi yang ada pada dirinya (Ferdiansyah et al., 2013; Anggoro, 2015). Pembelajaran adalah suatu usaha yang dilakukan pendidik melalui penyampaian ilmu pengetahuan kepada siswa dengan berbagai metode. Pembelajaran 
merupakan suatu proses perubahan perilaku bagi siswa sehingga siswa akan mengalami perubahan, baik perubahan dalam penguasaan ilmu pengetahuan maupun perubahan terhadap kemampuan yang dimilikinya. Salah satu kemampuan yang dikembangkan dalam pembelajaran adalah kemampuan berpikir kreatif matematis.

Kemampuan berpikir kreatif matematis adalah kemampuan dalam menyelesaikan permasalahan matematika dengan memberikan ide atau gagasan baru berdasarkan hasil pemikirannya sendiri dan mudah untuk dimengerti (Mursidik et al., 2015; Syahrir, 2016; Lince, 2016). Kemampuan berpikir kreatif penting untuk dimiliki oleh siswa dalam menyelesaikan permasalahan matematika agar siswa dapat terbiasa untuk menyelesaikan masalah matematika dengan menggunakan berbagai penyelesaian. Hal ini dapat melatih pemikiran siswa agar berpikir secara kreatif dalam menyelesaikan masalah matematika. Adapun indikator kemampuan berpikir kreatif matematis yang digunakan dalam penelitian ini adalah : (1) keluwesan, yaitu menyelesaikan masalah matematika dengan memberikan berbagai cara penyelesaian yang berbeda, (2) keaslian, yaitu menyelesaikan masalah matematika dengan memberikan ide atau gagasan baru berdasarkan hasil pemikirannya, dan (3) elaborasi, yaitu menyelesaikan masalah matematika dengan jawaban yang sistematis dan terperinci.

Kemampuan berpikir kreatif matematis yang dimiliki oleh siswa yang satu dengan yang lainnya tidaklah sama. Hal ini ditunjukkan oleh hasil penelitian Alfafah et al., (2019) yang menjelaskan bahwa kemampuan berpikir kreatif matematika siswa berbeda - beda. Berdasarkan tes yang telah diberikan memperoleh hasil bahwa terdapat siswa yang memenuhi seluruh indikator kemampuan berpikir kreatif matematis dalam menyelesaikan tes tersebut, namun ada juga siswa yang hanya memenuhi beberapa indikator kemampuan berpikir kreatif matematis. Hal ini menunjukkan bahwa kemampuan berpikir kreatif siswa satu dengan yang lainnya berbeda - beda. Perbedaan tersebut diduga karena sikap positif yang dimiliki oleh siswa dalam menyelesaikan masalah matematika. Sikap positif siswa pada saat menyelesaikan masalah matematika memiliki peran penting dalam menyelesaikan permasalahan matematika. Sikap positif ini disebut juga dengan resiliensi matematis.

Resiliensi matematis adalah sikap positif yang ditunjukkan dengan kegigihan, ketekunan, pantang menyerah dan percaya diri pada saat mengalami kesulitan dalam pembelajaran matematika (Asih et al., 2019; Hutauruk, 2019). Ketekunan sangat diperlukan bagi siswa dalam menyelesaikan permasalahan matematika dan juga dengan adaptasi yang baik agar dapat mengubah permasalahan matematika sebagai sebuah tantangan bukan sebagai suatu hambatan yang menjadikan siswa menjadi mudah menyerah untuk menyelesaikannya. Oleh karena itu, resiliensi sangat penting dalam pembelajaran matematika karena dengan resiliensi yang dimiliki oleh siswa, kemungkinan siswa dapat mengubah pemikiran bahwa masalah matematika adalah 


\section{Mandalika Mathematics and Education Journal \\ Volume 3 Nomor 1, Juni 2021 \\ e-ISSN 2715-1190| | p-ISSN 2715-8292 \\ DOI: http://dx.doi.org/10.29303/jm.v3i1.2577}

sebuah tantangan, dapat mengontrol emosi pada saat menyelesaikan masalah tersebut, memiliki keyakinan akan keberhasilan dalam menyelesaikan suatu permasalahan melalui usaha keras yang dilakukan oleh siswa. Indikator resiliensi matematis yang digunakan dalam penelitian ini adalah : (1) Emotional Regulation, yaitu menunjukkan kontrol emosi yang baik dalam menyelesaikan suatu permasalahan, (2) Optimist, yaitu menunjukkan sikap yakin dengan kemampuan yang dimilikinya dalam menyelesaikan masalah matematika, (3) Relation, yaitu menciptakan hubungan baik dengan lingkungan sekitar, (4) Analyze, yaitu mengidentifikasi suatu masalah matematika dan melakukan eksplorasi terhadap masalah tersebut untuk menemukan solusi penyelesaian, dan (5) Reaching out, yaitu menemukan solusi dari permasalahan matematika dengan kreativitas yang dimilikinya.

Berdasarkan pada uraian di atas, maka tujuan dari penelitian ini adalah untuk mendeskripsikan bagaimana kemampuan berpikir kreatif matematis siswa SMP Negeri 1 Banyumas jika ditinjau dari resiliensi matematis siswa.

\section{METODE}

Penelitian ini dilaksanakan pada kelas VII F di SMP Negeri 1 Banyumas pada semester genap tahun pelajaran 2019/2020. Prosedur penelitian ini dilakukan dengan menyusun instrumen angket resiliensi matematis dengan 25 pernyataan, menyusun instrumen tes kemampuan berpikir kreatif matematis yang terdiri dari 4 soal uraian, dan menyusun pedoman wawancara mengenai proses berpikir kreatif matematis siswa pada saat menyelesaikan soal tes. Kemudian, siswa mengisi angket resiliensi matematis melalui google form dan setelah itu siswa mengerjakan soal tes kemampuan berpikir kreatif matematis yang dibagikan secara online melalui aplikasi whatsapp. Setelah dibagikan angket dan tes, langkah selanjutnya yaitu melakukan wawancara kepada responden yang sudah dipilih dengan teknik purposive sampling sehingga diperoleh 9 responden dengan masing - masing 3 siswa berada pada kategori resiliensi matematis tinggi, sedang, dan rendah. Teknis analisis data dilakukan dengan 3 tahap, yaitu reduksi, penyajian data, dan penarikan kesimpulan. Uji keabsahan data menggunakan triangulasi teknik.

\section{HASIL DAN PEMBAHASAN}

Hasil dan pembahasan tersaji pada data dan deskripsi berikut.

\subsection{Kemampuan berpikir kreatif matematis siswa kategori resiliensi matematis tinggi}

Gambar 1 di bawah ini adalah contoh butir soal kemampuan kreatif matematis siswa yang mengukur indikator keluwesan. 
1. Diketahui suatu persegi panjang dengan perbandingan ukurannya adalah $4: 1$ dan keliling $50 \mathrm{~cm}$.

a. Adakah bangun lain yang luasnya sama, tetapi bentuk dan ukurannya berbeda dengan bangun persegi panjang tersebut ?. Jika ada, sebutkan minimal 3 bangun tersebut beserta ukurannya.

Gambar 1. Butir soal tes kemampuan kreativitas matematis (indikator keluwesan)

\begin{tabular}{|c|c|c|}
\hline 1. & Ponjang dan luas persegi panjang & (9) Trapestum \\
\hline & $2 \times(p+1)=50$ & 1. alas bagian otas $=5 \mathrm{~cm}$ \\
\hline & $2 x(4 x+x)=50$ & diat bagian bawah $=15 \mathrm{~cm}$ \\
\hline & $2 \pi 5 x=50$ & tinggi $=10 \mathrm{~cm}$ \\
\hline & $10 x=50$ & 2. alos bagan atas = $15 \mathrm{~cm}$ \\
\hline & $x=\frac{50}{10}$ & Alas bagin bavah $=25$ an \\
\hline & 10 & tinggi $=5 \mathrm{~cm}$. \\
\hline & $x=5$ & \\
\hline & & (1) Loyang- layang \\
\hline & Porjang $=4 x=4 \times 5=20 \mathrm{~cm}$ & drasganal $1=10 \mathrm{~cm}$ \\
\hline & lebor $=x=5 \mathrm{~cm}$ & dlagenal $2=20 \mathrm{~cm}$ \\
\hline & Loos $=P \times R$ & \\
\hline$=$ & $=20 \times 5=100 \mathrm{~cm}^{2}$ & \\
\hline & & \\
\hline & \multicolumn{2}{|c|}{ A. Ada. bangun perseg trapesium, dun layang-layang. } \\
\hline & \multicolumn{2}{|l|}{ * Persegi } \\
\hline & $s \times s=10 \times 10=100 \mathrm{~cm}^{2}$ & \\
\hline
\end{tabular}

Gambar 2. Jawaban siswa dengan resiliensi matematis tinggi

Gambar 2 menunjukkan bahwa siswa dengan resiliensi tinggi menjawab terdapat 4 buah bangun datar yang memiliki ukuran berbeda namun dengan luas yang sama seperti luas persegi panjang yaitu $100 \mathrm{~cm}^{2}$. Subyek memberikan 3 buah bangun datar yang berbeda lengkap dengan ukuran-ukurannya. Pada saat dilakukan wawancara, subyek menjelaskan bahwa subyek mengikuti perintah pada butir soal yaitu membuat minimal 3 buah bangun datar lengkap dengan ukurannya. Subyek mencoba membuat beberapa bangun datar dan mencoba memasukkan beberapa angka agar saat dihitung dapat memiliki luas yang sama seperti luas persegi panjang yang terdapat pada soal. Sebelum mencari bangun datar tersebut, subyek terlebih dahulu mencari panjang dan lebar persegi panjang menggunakan perbandingan dan keliling persegi panjang yang telah diketahui pada soal, kemudian subyek menghitung luasnya. Setelah subyek menghitung luas persegi panjang, kemudian subyek mencari beberapa bangun datar dan mencari angka yang tepat agar luas bangun datar tersebut sama dengan luas persegi panjang. Subyek sangat yakin bahwa jawaban tersebut adalah benar karena subyek sudah menghitung berulang kali untuk memastikan apakah luasnya sama atau berbeda dengan luas persegi panjang. 


\section{Mandalika Mathematics and Education Journal \\ Volume 3 Nomor 1, Juni 2021 \\ e-ISSN 2715-1190 | | p-ISSN 2715-8292 \\ DOI: http://dx.doi.org/10.29303/jm.v3i1.2577}

Siswa dengan kategori resiliensi matematis tinggi dapat menyelesaikan permasalahan matematika dengan menggunakan lebih dari satu cara penyelesaian sesuai dengan ketentuan pada soal. Hal ini karena siswa memiliki sikap tangguh dan tidak mudah putus asa pada saat mengerjakan soal matematika sehingga siswa terus berusaha mencari cara penyelesaian yang lain untuk menjawab soal yang diberikan. Sejalan dengan penelitian yang dilakukan oleh Dilla et al., (2018) dan Ansori dan Hindriyanto (2020) bahwa siswa dengan kategori resiliensi matematis tinggi lebih tekun dan tangguh, serta yakin atau percaya diri sehingga siswa terus berusaha untuk menjawab soal matematika dengan pantang menyerah.

Kontrol emosi yang baik pada saat menjawab soal juga dimiliki oleh siswa dengan kategori resiliensi matematis tinggi sehingga siswa dapat memunculkan kreativitasnya dengan memunculkan ide baru berdasarkan hasil pemikirannya sendiri. Pernyataan tersebut menunjukkan salah satu ciri resiliensi matematis yang dikemukakan oleh Hendriana, Rohaeti \& Sumarmo (2017) yaitu memunculkan ide baru dalam mencari solusi kreatif terhadap suatu permasalahan. Siswa memiliki kontrol emosi dan kepercayaan diri yang baik sehingga siswa dapat mengontrol rasa takut akan jawaban yang ditulisnya. Oleh karena itu, siswa terdorong untuk melakukan hal - hal yang tidak biasa dilakukan oleh orang lain dan menyelesaikan soal dari sudut pandang yang berbeda, sehingga kreativitas akan muncul berdasarkan hasil pemikiran siswa sendiri.

Selain itu, siswa juga menyelesaikan permasalahan matematika dengan jawaban yang sistematis dan rinci. Hal tersebut dikarenakan analisis siswa yang baik terhadap soal sehingga siswa dapat menuliskan jawaban dengan detail serta menemukan solusi atau penyelesaian yang baik berdasarkan pada analisis yang sudah dilakukan oleh siswa. Ansori dan Hindriyanto (2020) juga mengatakan bahwa siswa yang memiliki resiliensi matematis tinggi, dapat menjawab soal matematika dengan baik. Siswa menuliskan jawaban soal matematika dengan langkah - langkah yang sistematis dan terperinci, baik pada langkah penyelesaian maupun pada penulisan simbol dan lain sebagainya. Selain itu, siswa juga memiliki sikap tekun dalam menyelesaikan soal matematika yang diberikan sehingga jawaban tersebut ditulis oleh siswa dengan hati - hati dan teliti. Pernyataan tersebut sejalan dengan hasil penelitian oleh Dilla et al., (2018) yang mengatakan bahwa siswa dengan resiliensi matematis tinggi dapat memahami konsep soal dengan baik serta menjawab soal dengan jawaban yang tepat dan terperinci.

\subsection{Kemampuan berpikir kreatif matematis siswa kategori resiliensi matematis sedang}

Gambar 3. Menunjukkan soal yang mengukur kemampuan kreativitas matematis dengan indikator keaslian, sedang gambar 4 adalah contoh jawaban siswa pada kategori resiliensi matematis sedang. 


\section{Hafid mempunyai kertas karton berbentuk persegi dengan ukuran $50 \mathrm{~cm} \times 50 \mathrm{~cm}$. Hafid ingin membuat sebanyak - banyaknya jajargenjang dengan luas $300 \mathrm{~cm}^{2}$ dari kertas karton tersebut. Ukuran dari jajargenjang diperbolehkan berbeda - beda. \\ a. Sketsalah jajargenjang tersebut pada kertas karton berbentuk persegi.}

Gambar 3. Butir soal tes kemampuan kreativitas matematis (indikator keaslian)

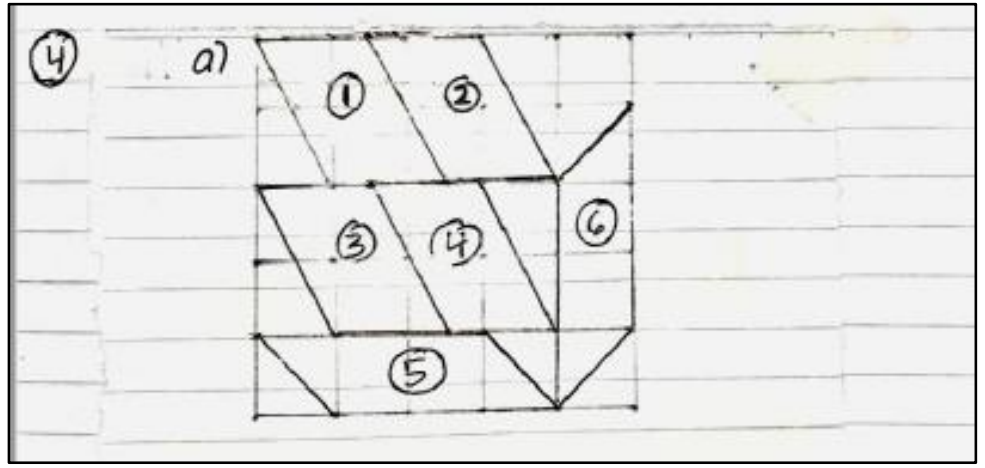

Gambar 4. Jawaban siswa dengan resiliensi matematis sedang

Gambar 4 memperlihatkan hasil tes tertulis oleh subyek dimana subyek membuat sketsa 6 buah bangun jajargenjang dengan ukuran yang berbeda jika diperhatikan dengan baik, namun tidak diketahui berapa ukuran untuk masing-masing jajargenjang tersebut sehingga tidak dapat diketahui pula apakah luas jajargenjang tersebut sebesar $300 \mathrm{~cm} 2$ atau justru berbeda. Oleh sebab itu, dilakukan wawancara dengan subyek untuk memperoleh informasi mengenai jawaban pada gambar 4 tersebut. Berdasarkan hasil wawancara, diperoleh informasi bahwa subyek membuat 6 buah sketsa jajargenjang adalah agar petak - petak persegi berukuran $10 \mathrm{~cm}$ tersebut dapat terisi dengan baik, sehingga saat seluruh petak - petak terisi, subyek menemukan 6 buah jajargenjang yang dapat subyek sketsakan. Subyek menyadari bahwa terdapat 4 jajargenjang yang luas sama dengan luas jajargenjang pada soal, sedangkan untuk jajargenjang kelima dan keenam memiliki luas yang sama dengan luas jajargenjang pada soal. Oleh karena itu, subyek membuat sketsa jajargenjang dengan satu ukuran yang memiliki luas sama dengan luas jajargenjang pada soal. Subyek menjelaskan ukuran dari jajargenjang tersebut adalah $20 \mathrm{~cm} \times 15 \mathrm{~cm}$ dan $30 \mathrm{~cm} \times 10 \mathrm{~cm}$ sehingga luasnya adalah $300 \mathrm{~cm}^{2}$.

Siswa dengan kategori resiliensi matematis sedang dapat menyelesaikan permasalahan matematika dengan memberikan lebih dari satu cara penyelesaian berbeda sesuai dengan ketentuan yang ada pada soal. Hal ini dikarenakan siswa dengan kategori resiliensi matematis sedang juga memiliki sikap tangguh saat dihadapkan pada suatu permasalahan. Oleh karena itu, siswa terus berusaha menjawab soal matematika 


\section{Mandalika Mathematics and Education Journal \\ Volume 3 Nomor 1, Juni 2021 \\ e-ISSN 2715-1190| | p-ISSN 2715-8292 \\ DOI: http://dx.doi.org/10.29303/jm.v3i1.2577}

dengan baik sesuai yang diharapkan pada soal. Siswa berusaha dan yakin dengan kemampuan yang dimilikinya sehingga tidak mudah menyerah dalam kesulitan sampai berhasil menemukan jalan keluar dari permasalahan tersebut.

Siswa dengan kategori resiliensi sedang cenderung mengalami kesulitan dalam menjawab soal. Hal tersebut sejalan dengan hasil penelitian 'Athiyah, Umah \& Syafrudin (2020) yang mengatakan bahwa siswa dengan kategori resiliensi sedang mengalami kesulitan saat menjawab soal matematika karena adanya dikap khawatir dan cemas ketika mengerjakan soal. Sikap cemas dan khawatir yang dimiliki seseorang dapat berasal dari kontrol emosi yang kurang baik sehingga dapat membuat pikiran seseorang menjadi terganggu dan cenderung khawatir untuk menjawab soal yang berbeda hingga akhirnya siswa menjawab soal sesuai perintah yang diberikan pada soal. Siswa tidak mencoba menjawab soal dari sudut pandang yang berbeda sehingga siswa tidak dapat memunculkan sesuatu yang baru berdasarkan hasil pemikirannya sendiri. Hal tersebut berarti bahwa siswa kategori resiliensi matematis sedang memiliki kepercayaan diri yang lemah karena khawatir jika memberikan jawaban dari sudut pandang berbeda, siswa khawatir bahwa jawaban yang dituliskannya tidak sesuai dengan perintah pada soal. Jawaban yang ditulis oleh siswa kategori resiliensi matematis sedang sudah sistematis, namun masih kurang sempurna karena masih terdapat jawaban yang tidak rinci dalam penulisannya. Hal tersebut dikarenakan siswa dengan kategori resiliensi matematis sedang tidak memiliki analisis yang baik sehingga membuat siswa menjawab soal dengan kurang teliti. Sebagaimana yang dikemukakan oleh Ansori dan Hindriyanto (2020) bahwa jawaban tes siswa dengan kategori resiliensi sedang masih ada yang kurang tepat.

\subsection{Kemampuan berpikir kreatif matematis siswa kategori resiliensi matematis rendah}

Gambar 5. Menunjukkan soal yang mengukur kemampuan kreativitas matematis dengan indikator elaborasi, sedang gambar 6 adalah contoh jawaban siswa pada kategori resiliensi matematis rendah.

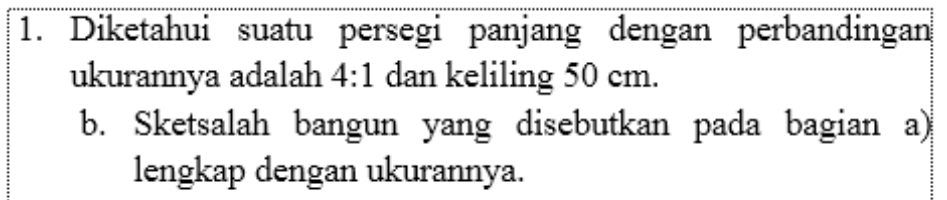

Gambar 5. Butir soal tes kemampuan kreativitas matematis (indikator elaborasi) 


\section{Mandalika Mathematics and Education Journal}

Volume 3 Nomor 1, Juni 2021

e-ISSN 2715-1190 | | p-ISSN 2715-8292

DOI: http://dx.doi.org/10.29303/jm.v3i1.2577

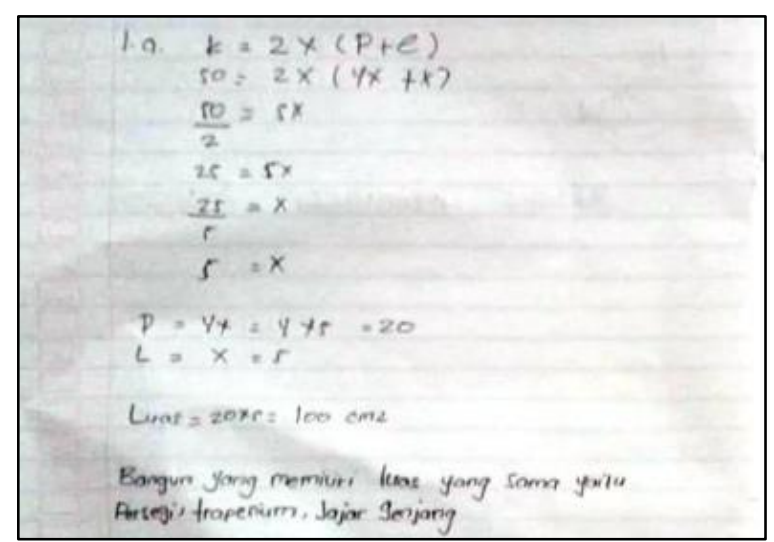

Gambar 6. Jawaban siswa dengan resiliensi matematis rendah

Subyek menjawab soal tersebut tanpa terlebih dahulu menuliskan informasi yang diketahui pada soal termasuk juga tidak membuat gambar dari bangun datar yang diketahui pada soal. Jawaban yang ditulis oleh subyek terlihat sistematis namun kurang rinci sebab informasi mengenai yang diketahui pada soal tidak disampaikan oleh subyek sehingga jika tidak membaca soal, tidak dapat memahami apa yand dimaksud oleh subyek. Berdasarkan hasil wawancara, diperoleh informasi bahwa subyek terbiasa untuk langsung menjawab pertanyaan tanpa terlebih dahulu menulis informasi yang diketahui pada soal. Hal ini dikarenakan agar subyek dapat mempersingkat waktu dengan langsung menjawab soal.

Siswa dengan kategori resiliensi rendah menyelesaikan permasalahan matematika dengan satu cara penyelesaian. Hal tersebut berarti bahwa jawaban siswa tidak memenuhi ketentuan yang ada pada soal. Siswa hanya dapat memberikan satu cara penyelesaian dalam menjawab soal matematika dikarenakan siswa dengan kategori resiliensi matematis rendah memiliki sikap tangguh yang rendah atau dengan kata lain siswa memiliki sikap mudah menyerah dalam menghadapi kesulitan. Pernyataan tersebut sejalan dengan hasil penelitian yang telah dilakukan oleh 'Athiyah, Umah \& Syafrudin (2020) siswa dengan kategori resiliensi matematis rendah mengalami kesulitan dalam memahami suatu masalah karena tidak dapat memahami konsep dengan baik sehingga tidak dapat membuat strategi yang tepat dalam menyelesaikan soal matematika yang diberikan. Pernyataan tersebut juga diperkuat oleh penelitian Supriatna dan Zulkarnaen (2019) bahwa siswa yang memiliki resiliensi rendah akan mudah menyerah dalam menjawab soal matematika. Pernyataan tersebut sejalan dengan hasil penelitian oleh Maftukhah et al., (2017) yang mengatakan bahwa siswa dengan pengendalian emosi yang rendah kebanyakan hanya berpatokan pada rumus yang sudah dipelajari sehingga akan kesulitan untuk menerapkan rumus yang berbeda.

Rendahnya sikap tangguh yang dimiliki oleh siswa dengan kategori resiliensi matematis rendah juga dikarenakan rendahnya kontrol emosi sehingga dalam menjawab soal matematika, siswa tidak dapat memunculkan ide baru. Ide yang tidak muncul pada jawaban siswa dengan kategori resiliensi rendah disebabkan karena siswa 


\section{Mandalika Mathematics and Education Journal \\ Volume 3 Nomor 1, Juni 2021 \\ e-ISSN 2715-1190| | p-ISSN 2715-8292 \\ DOI: http://dx.doi.org/10.29303/jm.v3i1.2577}

tidak dapat fokus pada saat menjawab soal. Siswa cenderung panik dan khawatir terhadap jawaban yang ditulisnya sehingga siswa tidak dapat berpikir dengan tenang untuk menemukan jawaban tersebut.

Jawaban yang ditulis oleh siswa kategori resiliensi rendah juga sudah sistematis, namun dalam penulisannya masih terdapat beberapa langkah yang tidak detail. Hal ini dikarenakan siswa tidak memiliki analisis yang baik terhadap suatu masalah sehingga membuat siswa merasa bingung dalam memahami maksud dari soal yang diberikan.. Siswa cenderung mengakhiri jawaban dengan apa adanya ketika tidak menemukan hasil akhir jawaban sesuai yang diharapkan pada soal dan melanjutkan untuk menjawab soal berikutnya. Hal ini sejalan dengan yang dikemukakan oleh Marasabessy (2020) bahwa siswa yang tidak yakin dengan kemampuan yang dimilikinya akan menghindar dari permasalahan yang sulit tanpa menyelesaikan terlebih dahulu masalah tersebut. Hal ini seperti yang dijelaskan oleh hasil penelitian Ansori dan Hindriyanto (2020) bahwa siswa dengan resiliensi rendah tidak mampu menjawab soal karena tidak dapat menganalisa soal tersebut dengan baik. Siswa tidak dapat memahami konsep soal dengan baik sehingga tidak dapat memberikan jawaban dengan baik pula. Selain itu, karena siswa juga tidak tekun pada saat menjawab soal sehingga jawaban yang ditulis oleh siswa dengan kategori resiliensi rendah masih terdapat beberapa yang kurang rinci. Siswa juga tidak memeriksa kembali jawabannya karena siswa khawatir ketika memeriksa ulang hasil pekerjaannya, ternyata jawaban tersebut salah dan siswa harus mencari jawaban lain yang berbeda dari jawaban sebelumnya karena jawaban sebelumnya salah.

\section{PENUTUP}

Hasil penelitian menunjukkan: (1) siswa kategori resiliensi matematis tinggi mampu memberikan berbagai penyelesaian berbeda, serta memunculkan ide baru dengan jawaban yang sistematis dan terperinci, (2) siswa kategori resiliensi matematis sedang mampu memberikan lebih dari satu penyelesaian yang berbeda dengan jawaban yang sistematis namun tidak rinci, dan (3) siswa kategori resiliensi matematis rendah mampu menyelesaikan permasalahan matematika dengan jawaban yang sistematis.

\section{UCAPAN TERIMA KASIH}

Terima kasih kepada Program Studi Pendidikan Matematika, Universitas Muhammaduyah Purwokerto dan SMP Negeri 1 Banyumas yang telah memberikan izin dan bantuannya, sehingga penelitian ini dapat diselesaikan dengan baik.

\section{REFERENSI}

Alfafah, A. N., Aniswita \& Firmanti, P.(2019).Kemampuan Berpikir Kreatif Siswa dalam Memecahkan Masalah Matematika Kelas VIII.C di SMP Negeri 1 Bukittinggi.Journal for Research in Mathematics Learning (JURING),2(3),257 - 264. 
Ansori, A., \& Hindriyanto, Y.(2020).Analisis Kemampuan Koneksi Ditinjau Berdasarkan Kemampuan Resiliensi Matematis Siswa.Jurnal Kajian Pendidikan Matematika (JKPM),5(2),253-262.

Asih, K. S., Isnarto., Sukestiyarno \& Wardono.(2019).Resiliensi Matematis pada Pembelajaran Discovery Learning dalam Upaya Meningkatkan Komunikasi Matematika.Prosiding Seminar Nasional Matematika (PRISMA),2,862 - 868.

Athiyah, F., Umah, U., \& Syafrudin,T.(2020).Pengaruh Mathematical Resilience Terhadap Kemampuan Pemecahan Masalah Matematis Siswa.Jurnal Kajian Pendidikan Matematika (JKPM),5(2),223 - 234 .

Dilla, S. C., Hidayat, W.,\&Rohaeti, E. E.(2018).Faktor Gender dan Resiliensi dalam Pencapaian Kemampuan Berpikir Kreatif Matematis Siswa SMA.Journal of Medives,2(1),129 - 136.

Ferdiansyah, F., Suherman, E., \& Yulianti, K.(2013).Penerapan Model Pembelajaran Osborn untuk Meningkatkan Kemampuan Berpikir Kreatif Matematis Siswa SMP. Jurnal Online Pendidikan Matematika Kontemporer, 1(1),1-12.

Hendriana, H., Rohaeti, E. E., \& Sumarmo, U.(2017).Hard Skills and Soft Skills Matematik Siswa. Bandung : Refika Aditama.

Hutauruk, A. JB.(2019).Perilaku Resiliensi Matematis Mahasiswa Melalui Model Problem Based Learning dengan Pendekatan Metakognitif.Journal of Mathematics Education and Applied (SEPREN),1(1),7 - 16.

Lince, Ranak.(2016).Creative Thinking Ability to Increase Student Mathematical of Junior High School by Applying Models Numbered Heads Together.Journal of Education and Practice, $7(6), 206-212$.

Maftukhah, N. A., Nurhalim,K., \& Isnarto.(2017).Kemampuan Berpikir Kreatif dalam Pembelajaran Model Connecting Organizing Reflecting Extending Ditinjau dari Kecerdasan Emosional.Journal of Primary Education,6(3),267 - 276.

Marasabessy, Rosida.(2020).Kajian Kemampuan Self Efficacy Matematis Siswa Dalam Pemecahan Masalah Matematika.Jurnal Riset Teknologi dan Inovasi Pendidikan (JARTIKA),3(2), 168 - 183.

Mursidik, E. M., Samsiyah, N., \& Rudyanto, H. E.(2015).Kemampuan Berpikir Kreatif Dalam Memecahkan Masalah Matematika Open - Ended Ditinjau Dari Tingkat Kemampuan Matematika Pada Siswa Sekolah Dasar.Journal Pedagogia,4(1),23 - 33.

Supriatna, A., \& Zulkarnaen, R.(2019).Studi Kasus Tingkat Kecemasan Matematis Siswa SMA.Prosiding Seminar Nasional Matematika dan Pendidikan Matematika (SESIOMADIKA). $730-735$.

Syahrir.(2016).Pengembangan Perangkat Pembelajaran Matematika SMP Untuk Meningkatkan Kemampuan Berpikir Kreatif.Jurnal Ilmiah Mandala Education (JIME),2(1),436 - 441. 